\title{
Komposisi Nekleotida Sekuen Gen Mitokondria 16S rRNA Ikan Bilih (Mystacoleucus padangensis Bleeker, 1852) Danau Singkarak, Solok, Sumatera Barat
}

\author{
LIZA OKTAVIA $^{1}$, TUTY ARISURYANTI ${ }^{1}$ \\ ${ }^{1}$ Laboratorium Genetika dan Pemuliaan, Fakultas Biologi, Universitas Gadjah Mada \\ Jl. Teknika Selatan, Sekip Utara, Sleman, Yogyakarta. 55281 \\ Email: liza.oktavia@mail.ugm.ac.id; tuty-arisuryanti@ugm.ac.id
}

Received 14 May 2018; Received in revised form 3 June 2018;

Accepted 27 June 2018; Available online 26 November 2018

\begin{abstract}
Bilih fish (Mystacoleucus padangensis) is one of the endemic fish inhabited at West Sumatra and is exploited extensively to meet market demands due to high nutritional value. The fish is also commonly exported to Malaysia and Singapore in dried processed form. However, research on composition of mtDNA $16 S$ nucleotide as a part of genetic characterization of bilih fish has not been examined. Genetic characterization of the fish is useful for its conservation and breeding program. Therefore, the aim of this research was to determine composition of mtDNA $16 S$ nucleotide of bilih fish (Mystacoleucus padangensis Bleeker, 1852) collected from Singkarak Lake, Solok, West Sumatra. This research used a PCR method with $16 S$ universal primers: $16 \mathrm{Sar}$ and16Sbr. The results showed that the average of mtDNA $16 S$ nucleotide composition was $\mathrm{T}=22.63 \%, \mathrm{C}=24.38 \%, \mathrm{~A}=31.24 \%$ and $\mathrm{G}=21.76 \%$ whereas the average of $\mathrm{A}+\mathrm{T}$ and $\mathrm{C}+\mathrm{G}$ were $53.86 \%$ and $46.14 \%$ respectively. The difference in the mtDNA $16 \mathrm{~S}$ nucleotide between the two bilih fish samples was similar between $\mathrm{T}, \mathrm{C}$, and $\mathrm{A}$ composition $(0,04 \%)$ whereas the $\mathrm{G}$ composition was high $(0,13 \%)$. In addition, the average rate of nucleotide composition $\mathrm{A}+\mathrm{T}$ and $\mathrm{G}+\mathrm{C}$ between the two bilih fish samples was similar $(0,08 \%)$. This result revealed that there was genetic variation between the two bilih fish samples examined in this study based on composition of mtDNA $16 S$ nucleotide which is the first published data we reported.
\end{abstract}

Keywords: bilih fish, genetic variation, mtDNA 16S, nucleotide composition

\section{INTISARI}

Ikan bilih (Mystacoleucus padangensis) merupakan salah satu ikan endemik di Sumatera Barat yang banyak diekploitasi untuk dikonsumsi oleh masyarakat Sumatera karena bernilai gizi tinggi. Selain itu ikan bilih juga diekspor ke Malaysia dan Singapura dalam bentuk olahan. Namun demikian penelitian mengenai komposisi nukleotida gen mitokondria 16S ikan bilih belum banyak dilakukan. Penelitian karakterisasi genetik penting dilakukan sebagai upaya konservasi maupun program pemuliaan. Oleh karena itu penelitian ini bertujuan untuk mengidentifikasi komposisi nukleotida gen mitokondria 16S dari ikan bilih (Mystacoleucus padangensis Bleeker, 1852) yang dikoleksi dari Danau Singkarak, Solok, Sumatera Barat. Pada penelitian ini dua sampel ikan bilih (Bilih-1 dan Bilih-2) diambil dari Danau Singkarak, Solok, Sumatera Barat. Metode yang digunakan dalam penelitian ini yaitu metode PCR dengan menggunakan primer forward $16 \mathrm{Sar}$ dan primer reverse $16 \mathrm{Sbr}$. Hasil penelitian menunjukkan bahwa kedua sampel ikan bilih yang diambil dari Danau Singkarak, Solok, Sumatera Barat memiliki rata-rata komposisi nukleotida $\mathrm{T}=22,63 \%, \mathrm{C}=24,38 \%$, $\mathrm{A}=31,24 \%$ dan $\mathrm{G}=21,76 \%$, sedangkan rata-rata komposisi nukleotida $\mathrm{A}+\mathrm{T}=53,86 \%$ dan $\mathrm{G}+\mathrm{C}=46,14 \%$. Selain itu kedua ikan bilih yang diteliti memiliki perbedaan komposisi nukleotida T, C, dan A sejumlah 0,04\%, sedangkan perbedaan komposisi nukleotida $\mathrm{G}$ kedua ikan bilih cukup tinggi yaitu $0,13 \%$. Adapun perbedaan komposisi $\mathrm{A}+\mathrm{T}$ dan $\mathrm{G}+\mathrm{C}$ adalah sama yaitu $0,08 \%$. Perbedaan komposisi nukleotida sekuen gen mitokondria $16 S$ antara ikan bilih yang diteliti menunjukkan adanya variasi genetik intra populasi. Hasil penelitian ini merupakan yang pertama kali dilaporkan. Hasil penelitian komposisi nukleotida gen 16S rRNA ini diharapkan dapat melengkapi data karakterisasi genetik ikan bilih yang penting untuk upaya konservasi maupun program pemuliaan.

Kata Kunci: gen 16S, ikan bilih, komposisi nukleotida, variasi genetik

\section{PENDAHULUAN}

Indonesia merupakan negara yang memiliki banyak danau air tawar (Dudgeon, 2000; Haryani, 2013), salah satu diantaranya adalah Danau Singkarak yang terletak di Kabupaten Solok, Propinsi Sumatera Barat.
Danau Singkarak merupakan salah satu danau di Sumatera Barat yang memiliki beberapa fungsi yaitu sebagai tempat irigasi, tempat wisata, perikanan, dan pembangkit tenaga listrik. Pada Danau Singkarak tersebut terdapat salah satu jenis ikan endemik yaitu ikan bilih 
yang daerah penyebarannya terbatas (Umar dan Kartamihardja, 2011). Menurut Kottelat (2013) ikan bilih termasuk dalam ordo Cypriniformes, famili Cyprinidae dan sub famili Cyprininae. Berdasarkan karakter morfologi, ikan bilih termasuk dalam spesies Mystacoleucus padangensis Bleeker, 1852 dan telah menjadi valid species dengan Danau Singkarak sebagai type locality.

Ikan bilih memiliki ukuran kecil dengan panjang ikan bilih dewasa berkisar antara 5,8$10,7 \mathrm{~cm}$ dan panjang rata-rata $8,9 \mathrm{~cm}$. Berat badan ikan bilih berkisar antara 3-19,5 gr dan berat rata-rata 6,8 gr dengan sisik bagian perut sampai ekor bagian bawah berwarna putih keperakan. Secara umum ikan bilih menyukai perairan yang jernih, suhu perairan rendah (26$28{ }^{\circ} \mathrm{C}$ ) dan daerah litoral perairannya berbatu kerikil dan atau pasir. Ikan bilih melakukan reproduksi dengan mengikuti aliran air di sungai yang bermuara di danau. Ikan-ikan bilih betina melepaskan telur dan pada waktu yang sama ikan-ikan bilih jantan melepaskan sperma untuk membuahi telur (Kartamihardja dan Purnomo, 2006; Kartamihardja, 2015; Nofrita dkk., 2013). Telur yang telah dibuahi berwarna transparan dan tenggelam di dasar sungai dan kemudian hanyut terbawa arus air masuk ke danau. Telur-telur tersebut akan menetas di danau sekitar 19 jam setelah dibuahi pada suhu air antara $27-28^{\circ} \mathrm{C}$ (Febriani, 2010; Suryanti dkk., 2017).

Ikan bilih banyak diminati oleh masyarakat setempat sebagai ikan konsumsi karena memiliki nilai gizi yang tinggi. Ikan bilih merupakan sumber protein hewani dengan kandungan protein sebesar 13,02\%. Di samping itu ikan bilih memiliki kandungan mineral seperti kalsium sebesar 2,2\%, magnesium $0,18 \%$, dan fosfor $1,2 \%$ (Permata dan Martius, 2015). Hasil tangkapan ikan bilih ini selain dikonsumsi lokal juga diekspor ke Malaysia dan Singapura dalam bentuk olahan (Patriono dkk., 2010). Eksploitasi ikan bilih untuk kebutuhan konsumsi dan ekspor tidak diikuti oleh upaya konservasi maupun budidaya ikan bilih, sehingga populasi dan produksi ikan bilih dikhawatirkan akan menurun setiap tahunnya. Berdasarkan hal tersebut maka diperlukan penelitian terkait karakterisasi genetik ikan bilih untuk program budidaya dan konservasi.

Karakterisasi genetik secara spesifik dapat diidentifikasi dengan menggunakan gen mitokondria (Satoh et al., 2016; Tanaka and Aranishi, 2016). Hal ini disebabkan karena gen mitokondria bersifat maternal sehingga pewarisannya tidak ditemukan adanya rekombinasi seperti halnya gen inti (Hartwell et al., 2015). Gen mitokondria 16S rRNA merupakan gen penanda yang penting dalam karakterisasi dan identifikasi genetik spesies serta untuk mengamati hubungan filogenetik inter spesies (Li et al., 2008; Singh et al., 2013). Adapun penggunaan gen mitokondria 16S rRNA untuk karakterisasi dan identifikasi spesies telah banyak digunakan pada ikan antara lain pada ikan belut (Arisuryanti et al., 2016), ikan Piscirickettsia salmonis dari Chili Selatan (Contreras-Lynch et al., 2015), dan ikan gabus (Firlianty et al., 2014).

Penelitian biologi ikan bilih telah banyak dilakukan diantaranya mengenai karakterisasi morfologi dan kromosom ikan bilih (Roesma dkk., 2012) serta reproduksi dan pembudidayaan ikan bilih (Syandri dkk., 2013). Akan tetapi, penelitian mengenai komposisi nukleotida sekuen gen mitokondria 16S ikan bilih di Indonesia yang merupakan bagian dari karakterisasi genetik ikan bilih ( $M$. padangensis) belum pernah dilakukan. Hal ini didukung belum adanya basis data gen mitokondria 16S ikan bilih (M. padangensis) di GenBank.

\section{METODE}

Pengambilan sampel dan penyimpanan sampel. Dua sampel ikan bilih disampling dari Danau Singkarak, Kabupaten Solok, Propinsi Sumatera Barat $\left(0^{\circ} 36^{\prime} 44,17^{\prime \prime}\right.$ S dan $100^{\circ} 32^{\prime} 21,14$ ” E) (Gambar 1) dengan menggunakan jaring/net. Tiap sampel ikan bilih diambil filet dagingnya dan selanjutnya dimasukkan ke dalam tube $1,5 \mathrm{ml}$ yang kemudian dipreservasi dengan menggunakan etanol absolut $99 \%$. Filet dari sampel-sampel ikan bilih tersebut selanjutnya dibawa ke Laboratorium Genetika dan Pemuliaan, Fakultas Biologi UGM dan disimpan pada suhu $4^{0} \mathrm{C}$ hingga digunakan. 

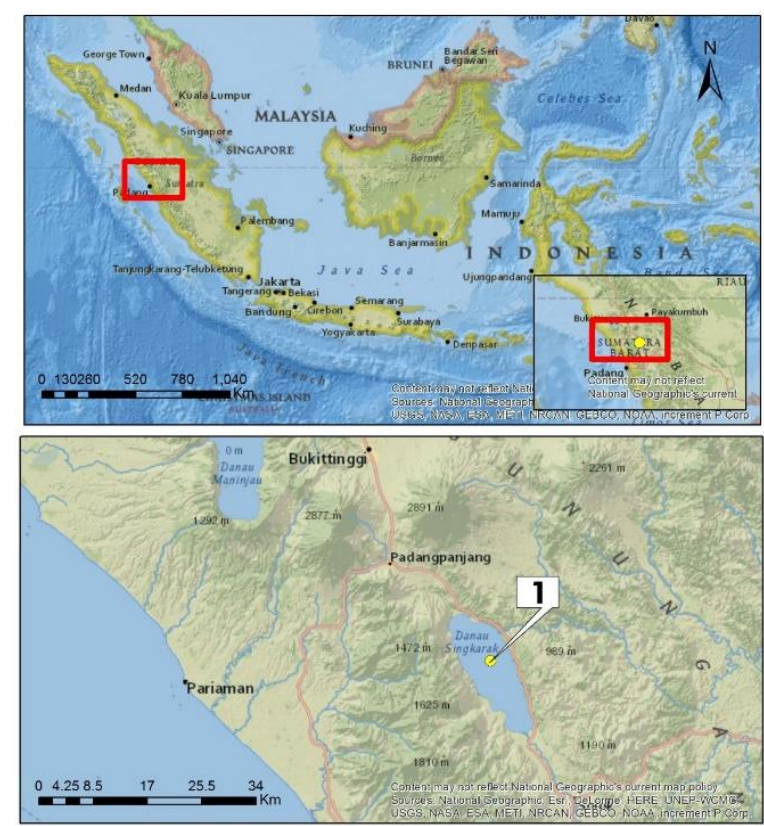

Gambar 1. Peta titik pengambilan sampel Mystacoleucus padangensis di Danau Singkarak, Solok, Sumatera Barat

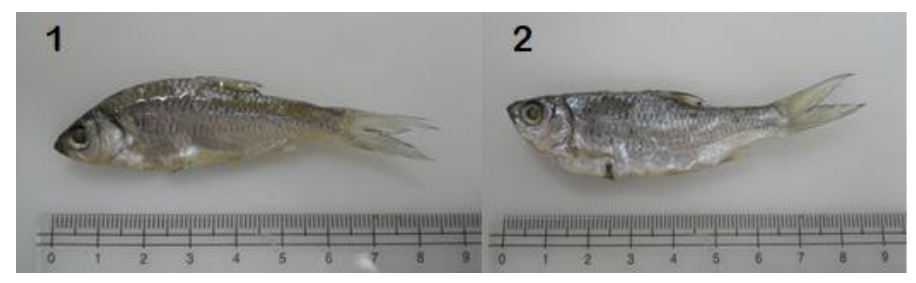

Gambar 2. Ikan bilih (Bilih-1 dan Bilih-2) yang dikoleksi dari Danau Singkarak, Solok, Sumatera Barat

Isolasi DNA, amplifikasi DNA, dan elektroforesis ikan bilih. Penelitian isolasi DNA, amplifikasi DNA, dan elektroforesis dilakukan di Laboratorium Genetika dan Pemuliaan, Fakultas Biologi UGM. Pada penelitian ini digunakan Qiagen Dneasy Blood and Tissue Kit (QIAGEN, Valencia, CA, USA) untuk isolasi DNA filet ikan bilih yang dikoleksi dari Danau Singkarak, Solok, Sumatera Barat. Selanjutnya hasil isolasi DNA dari tiap sampel ikan bilih diamplifikasi dengan menggunakan primer 16Sar (5'CGCCTGTTTATCAAAAACAT-3') dan primer 16Sbr (5'-CCGGTCTGAAC TCAGATCACGT-3') (Kang dkk, 2015). Pada penelitian ini digunakan MyTaq HS Red Mix PCR Kit (Bioline) untuk amplifikasi PCR. Amplifikasi PCR menggunakan $50 \mu \mathrm{L}$ reaksi yang terdiri dari $2 \mu \mathrm{L}(50 \mathrm{ng} / \mu \mathrm{L})$ DNA genom yang ditambahkan $25 \mu$ L MyTaq HS Red Mix PCR Kit; $2 \mu \mathrm{M} \mathrm{MgCl}_{2} ; 0,6 \mu \mathrm{M}$ untuk tiap primer dan $11 \mu \mathrm{L} \mathrm{ddH}_{2} \mathrm{O}$. Sampel-sampel tersebut selanjutnya dimasukkan ke dalam thermal cycler (Biorad) dengan pengaturan siklus: pre-denaturasi pada suhu $95^{\circ} \mathrm{C}$ selama 1 menit yang diikuti dengan 35 siklus yang terdiri dari tahap denaturasi pada suhu $95^{\circ} \mathrm{C}$ selama 15 detik, annealing pada suhu $50^{\circ} \mathrm{C}$ selama 30 detik, dan extension pada suhu $72^{\circ} \mathrm{C}$ selama 30 detik dan bagian akhir dilakukan satu siklus dengan suhu $72^{\circ} \mathrm{C}$ selama 5 menit yang diikuti dengan hold pada suhu $4^{\circ} \mathrm{C}$ selama 4 menit. Selanjutnya hasil produk PCR sebanyak $2 \mu \mathrm{L}$ dielektroforesis pada gel agarose $1 \%$ yang ditambahkan dengan Gel Red untuk staining. Adapun DNA ladder (Bioline) digunakan sebagai marker untuk mendeteksi panjang fragmen PCR produk ( $\pm 500 \mathrm{bp}$ ). Selanjutnya elektroforesis dilakukan pada tegangan 100 volt dengan arus $400 \mathrm{~mA}$ selama 12 menit. Visualisasi fragmen DNA dilakukan dengan menggunakan UV lamp transilluminator (Daihan, Korea) dan pita-pita yang terlihat didokumentasi dengan GelDoc 
camera. Sampel selanjutnya dikirim ke First Base Sdn Bhd. (Malaysia) melalui P.T. Genetika Science untuk dipurifikasi dan disekuensing.

Analisis Data. Hasil sekuensing gen mitokondria 16S ikan bilih diamati dengan menggunakan program SeqMan dan EditSeq yang terdapat pada software DNASTAR (DNASTAR Inc., Madison, USA). Pada penelitian ini lajur forward dan reverse diamati secara cermat untuk memastikan tidak ditemukan ketidaksesuaian pada consensus sequence. Setelah hasil consensus sequence sesuai antara lajur forward dan reverse selanjutnya data sekuen masing-masing sampel dihitung komposisi nukleotidanya melalui program EditSeq pada menu DNA Statistics. Adapun komposisi $\mathrm{C}+\mathrm{G}$ divalidasi menggunakan program DnaSP v.5.10.01 (Librado and Rozas, 2009).

\section{HASIL}

Hasil amplifikasi gen mitokondria 16S pada ikan bilih yang diteliti (Bilih-1 dan Bilih2) menghasilkan panjang fragmen partial 627 bp (Gambar 3).

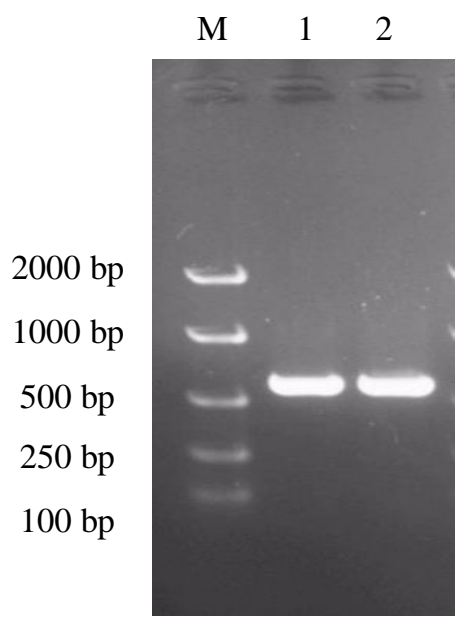

Gambar 3. Pita-pita DNA hasil amplifikasi PCR yang divisualisasikan dengan UV lamp trans-illuminator pada gel elektroforesis. M merupakan marker dari DNA Ladder yang digunakan. Angka 1 menunjukkan sampel Bilih1 dan angka 2 menunjukkan sampel Bilih-2.

Komposisi nukleotida dari panjang fragmen partial sekuen gen mitokondria $16 \mathrm{~S}$ kedua sampel ikan bilih yang diteliti dapat dilihat pada Tabel 1.

Tabel 1. Persentase komposisi nukleotida gen mitokondria 16S rRNA ikan bilih yang diteliti (Bilih-1 dan Bilih-2) dari panjang fragmen $627 \mathrm{bp}$

\begin{tabular}{ccccccc}
\hline Sampel & T(U) & C & A & G & A+T & C+G \\
\hline Bilih-1 & 22,61 & 24,36 & 31,21 & 21,82 & 53,82 & 46,18 \\
\hline Bilih-2 & 22,65 & 24,40 & 31,26 & 21,69 & 53,90 & 46,10 \\
\hline Rata-rata & 22,63 & 24,38 & 31,24 & 21,76 & 53,86 & 46,14 \\
\hline
\end{tabular}

Persentase komposisi nukleotida gen mitokondria 16S rRNA ikan M. marginatus dari GenBank sebagaimana terlihat pada tabel 2.

Tabel 2. Persentase komposisi nukleotida gen mitokondria 16S rRNA ikan M. marginatus yang diperoleh dari database GenBank dengan panjang fragmen $627 \mathrm{bp}$

\begin{tabular}{ccccccc}
\hline Sampel & T(U) & C & A & G & A+T & C+G \\
\hline AP011192 & 19,55 & 24,12 & 36,48 & 19,85 & 56,03 & 43,97 \\
\hline KF697091 & 19,56 & 24,14 & 36,44 & 19,86 & 56,00 & 43,99 \\
\hline HQ235712 & 19,78 & 23,68 & 36,47 & 20,07 & 56,25 & 43,75 \\
\hline DQ845913 & 19,76 & 23,67 & 36,51 & 20,06 & 56,27 & 43,78 \\
\hline Rata-rata & 19,66 & 23,90 & 36,48 & 19,96 & 56,14 & 43,87 \\
\hline
\end{tabular}




\section{PEMBAHASAN}

Komposisi nukleotida gen mitokondria 16S pada ikan bilih yang disampling dari Danau Singkarak, Solok, Sumatera Barat merupakan yang pertama kali dilaporkan. Hasil penelitian menunjukkan bahwa kedua sampel ikan bilih yang diambil dari Danau Singkarak, Solok, Sumatera Barat memiliki rata-rata komposisi nukleotida $\mathrm{T}=22,63 \%$, $\mathrm{C}=24,38 \%, \quad \mathrm{~A}=31,24 \%$ dan $\mathrm{G}=21,76 \%$, sedangkan rata-rata komposisi nukleotida $\mathrm{A}+\mathrm{T}=53,86 \%$ dan $\mathrm{G}+\mathrm{C}=46,14 \%$. Selain itu pada Tabel 1 tersebut tampak bahwa persentase komposisi nukleotida T $(22,65 \%)$, C $(24,40 \%)$ dan A $(31,26 \%)$ pada ikan Bilih-2 lebih tinggi dibandingkan dengan komposisi nukleotida $\mathrm{T}(22,61 \%), \mathrm{C}(24,36 \%)$ dan A $(31,21 \%)$ ikan Bilih-1. Sebaliknya persentase komposisi nukleotida $\mathrm{G}(21,82 \%)$ pada ikan Bilih-1 lebih tinggi dibandingkan dengan komposisi nukleotida G $(21,69 \%)$ ikan Bilih2. Adapun komposisi A+T $(53,90 \%)$ ikan Bilih-2 lebih tinggi dibandingkan dengan komposisi A+T $(53,82 \%)$ ikan Bilih-1 dan sebaliknya komposisi C+G $(46,18)$ ikan Bilih1 lebih tinggi dibanding ikan Bilih-2. Berdasarkan hal tersebut maka kedua sampel ikan bilih yang diteliti memiliki perbedaan komposisi nukleotida gen mitokondria $16 \mathrm{~S}$ yaitu kandungan $\mathrm{T}, \mathrm{C}$, dan A yang sama yaitu $0,04 \%$, sedangkan perbedaan komposisi $\mathrm{G}$ antara kedua ikan bilih yang diteliti yaitu $0,13 \%$. Adapun perbedaan komposisi nukleotida $\mathrm{A}+\mathrm{T}$ maupun $\mathrm{C}+\mathrm{G}$ adalah sama yaitu $0,08 \%$. Apabila dibandingkan dengan spesies lain yaitu $M$. marginatus dari database GenBank (Tabel 2) terlihat bahwa komposisi $\mathrm{T}, \mathrm{C}$ dan $\mathrm{G}$ serta komposisi $\mathrm{C}+\mathrm{G}$ ikan bilih $(M$. padangensis) yang diteliti lebih tinggi dibandingkan dengan $M$. marginatus.

Perbedaan komposisi nukleotida pada kedua ikan bilih yang diteliti tersebut memperlihatkan adanya indikasi variasi genetik intra-populasi ikan bilih di Danau Singkarak, Solok, Sumatera Barat berdasarkan sekuen gen mitokondria 16S rRNA. Menurut Dharmayanti (2011), variasi genetik memiliki peran yang penting bagi program pemuliaan, karena ikan-ikan dengan variasi genetik yang tinggi akan bertahan dengan adanya tekanan lingkungan termasuk serangan penyakit. Dengan demikian adanya variasi genetik intrapopulasi ikan bilih tersebut mengindikasikan bahwa ikan bilih dari Danau Singkarak dapat digunakan untuk program pemuliaan yang berkelanjutan agar eksploitasi ikan bilih dapat ditekan seperti halnya penelitian ikan belut yang telah dilakukan oleh Arisuryanti (2016); Arisuryanti et al. (2016).

Hasil penelitian variasi komposisi nukleotida sekuen gen mitokondria $16 \mathrm{~S}$ pada ikan bilih ini diharapkan dapat mendukung informasi data tentang variasi genetik ikan bilih yang ada di Indonesia khususnya di Sumatera. Penelitian lanjutan masih diperlukan untuk lebih melengkapi data variasi genetik ikan bilih yaitu penelitian polimorfisme ikan bilih menggunakan mikrosatelit.

\section{KESIMPULAN}

Rata-rata komposisi nukleotida sekuen gen mitokondria $16 \mathrm{~S}$ pada ikan bilih yaitu $\mathrm{T}=22,63 \% ; \quad \mathrm{C}=24,38 \% ; \quad \mathrm{A}=31,24 \% \quad$ dan $\mathrm{G}=21,76 \%$. Adapun perbedan komposisi nukleotida sekuen gen mitokondria $16 \mathrm{~S}$ pada $\mathrm{T}, \mathrm{C}$, dan A adalah sama yaitu 0,04\%, sedangkan perbedaan komposisi A+T maupun $\mathrm{C}+\mathrm{G}$ adalah $0,08 \%$. Perbedaan komposisi nukleotida tersebut mengindikasikan adanya variasi genetik pada sampel ikan bilih yang disampling dari Danau Singkarak, Solok, Sumatera Barat.

\section{UCAPAN TERIMA KASIH}

Penulis mengucapkan terima kasih kepada Lukman Hakim, S.Si. yang telah membantu dan mendampingi dalam melakukan penelitian di Laboratorium Genetika dan Pemuliaan, Fakultas Biologi UGM serta kepada Kepala Laboratorium Genetika dan Pemulian yang telah menyediakan fasilitas bagi berlangsungnya penelitian ini.

\section{DAFTAR PUSTAKA}

Arisuryanti T. 2016. Molecular Genetic and Taxonomic Studies of the Swamp Eel (Monopterus albus Zuiew 1793). [Dissertation]. Australia: Charles Darwin University. 
Arisuryanti T, Wei NWV, Austin C. 2016. Molecular evidence for determination cryptic species of Indonesian swamp eel populations using denaturing gradient gel electrophoresis (DGGE). AIP Conference Proceedings. New York: American Institute of Physics. pp. 1-6. https://doi.org/10.1063/1.4953534.

Contreras-Lynch S, Olmos P, Vargas A, Figueroa J, González-Stegmaier R, Enríquez R, Romero A. 2015. Identification and genetic characterization of Piscirickettsia salmonis in native fish from southern Chile. Diseases of Aquatic Organisms. vol 115: 233-244. https://doi.org/10.3354/dao02892.

Dharmayanti N. 2011. Filogenetika molekuler: metode taksonomi organisme berdasarkan sejarah evolusi. Wartazoa. vol 21(1): 110.

Dudgeon D. 2000. Conservation of freshwater biodiversity in Oriental Asia: Constraints, conflicts, and challenges to science and sustainability. Limnology. vol 1(3): 237243.

https://doi.org/10.1007/s102010070012.

Febriani L. 2010. Studi Makanan dan Pertumbuhan Ikan Bilih (Mystacoleucus padangensis) di Danau Singkarak, Sumatera Barat [Tesis]. Bogor: Institut Pertanian Bogor.

Firlianty, Suprayitno E, Nursyam H, Hardoko. 2014. Genetic Variation Analysis of Snakeheads (Channidae) in Central Kalimantan Using Partial 16s rRNA Gene. International Journal of Science and Technology (IJSTE). vol 3(2): 1-7.

Hartwell LH, Hood L, Goldberg M, Reynolds A, Silver L. 2015. Genetics: From Genes to Genomes $5^{\text {th }}$ Edition. New York: McGraw-Hill.

Haryani GS. 2013. Kondisi Danau di Indonesia dan Strategi Pengelolaannya. Prosiding Pertemuan Ilmiah Tahunan MLI I. Cibinong: Masyarakat Limnologi Indonesia. hal. 1-19.

Kartamihardja ES. 2015. Potential of culturebased fi sheries in Indonesian inland waters. Perspectives on culture-based fisheries developments in Asia. Bangkok:
Network of Aquaculture Centres in AsiaPacific.

Kartamihardja ES, and Purnomo K. 2006. Keberhasilan introduksi ikan bilih (Mystacoleucus padangensis) ke habitatnya yang baru di Danau Toba, Sumatera Utara. Prosiding Seminar Nasional Ikan IV. Jatiluhur: Masyarakat Iktiologi Indonesia. hal. 1-19.

Kottelat M. 2013. The fishes of the inland waters of Southeast Asia: A catalogue and core bibliography of the fishes known to occur in freshwaters, mangroves and estuaries. Raffles Bulletin of Zoology. vol 27: $1-663$. https://doi.org/10.1080/02701367.2001.1 0608936.

Li J, Wang X, Kong X, Zhao K, He S, Mayden RL. 2008. Variation patterns of the mitochondrial 16S rRNA gene with secondary structure constraints and their application to phylogeny of cyprinine fishes (Teleostei: Cypriniformes). Molecular Phylogenetics and Evolution. vol 47(2): 472-487. https://doi.org/10.1016/j.ympev.2007.09. 012.

Librado P, and Rozas J. 2009. DnaSP v5: A software for comprehensive analysis of DNA polymorphism data. Bioinformatics. vol 25(11): 1451-1452. https://doi.org/10.1093/bioinformatics/bt p187.

Nofrita, Dahelmi, Syandri H, Tjong DH. 2013. Hubungan Tampilan Pertumbuhan Dengan Karakteristik Habitat Ikan Bilih (Mystacoleucus padangensis Blekeer). Prosiding Semirata FMIPA Universitas Lampung. vol 1(1): 179-183.

Patriono E, Junaidi E, Sastra F. 2010. Fekunditas Ikan Bilih (Mystacoleucus padangensis Blkr.) di Muara Sungai Sekitar Danau Singkarak. Jurnal Penelitian Sains (JPS). vol 13(3): 55-58.

Permata A, dan Martius W. 2015. Kandungan zat gizi dan bakteri proteolitik pada produk olahan ikan bilih. Jurnal Teknologi Pertanian Andalas. vol 19(1): $10-14$. https://doi.org/https://doi.org/10.25077/jt 
pa.19.1.10-14.2015.

Roesma DI, Syaifullah S, Melyawati M. 2012. Pengamatan Kromosom Ikan Bilih (Mystacoleucus padangensis BLKR., Cyprinidae) dari Danau Singkarak Sumatera Barat Chromosomes Investigation of Bilih Fish (Mystacoleucus padangensis BLKR., Cyprinidae) from Singkarak Lake West Sumatera. Biospecies. vol 5(2): 1-4.

Satoh TP, Miya M, Mabuchi K, Nishida M. 2016. Structure and variation of the mitochondrial genome of fishes. $B M C$ Genomics. vol 17: 719. https://doi.org/10.1186/s12864-0163054-y.

Singh AK, Kumar R, Singh M, Mishra AK, Chauhan UK, Baisvar VS, Verma R, Nagpure NS, Kushwaha B. 2013. Mitochondrial 16S rRNA gene-based evolutionary divergence and molecular phylogeny of Barilius spp. The Journal of DNA Mapping, Sequencing, and Analysis. vol 26(1): 41-47. https://doi.org/https://doi.org/10.3109/19 401736.2013.815168.

Suryanti A, Sulistiono, Muchsin I, Kartamihardja ES. 2017. Habitat Pemijahan Dan Asuhan Ikan Bilih
Mystacoleucus padangensis (Bleeker, 1852) di Sungai Naborsahan, Danau Toba, Sumatera Utara. Bawal Widya Riset Perikanan Tangkap. vol 9(1): 33-42. https://doi.org/http://dx.doi.org/10.15578/ bawal.9.1.2017.33-42.

Syandri H, Azrita, Aryani N. 2013. Distribusi ukuran, reproduksi dan habitat pemijahan ikan bilih (Mystacoleucus padangensis Blkr.) di Danau Singkarak. Bawal Widya Riset Perikanan Tangkap. vol 5(1): 1-8. https://doi.org/http://dx.doi.org/10.15578/ bawal.5.1.2013.1-8.

Tanaka T, and Aranishi F. 2016. Comparative Genetic Characterization of Ark Shell Scapharca broughtonii in Northeast Asia. Journal of Shellfish Research. vol 35(2): 421-427. https://doi.org/https://doi.org/10.2983/03 5.035.0216.

Umar C, dan Kartamihardja ES. 2011. Hubungan Panjang-Berat Kebiasaan Makan dan Kematangan Gonad Ikan Bilih (Mystacoleucus padangensis) di Danau Toba Sumatera Utara. Bawal Widya Riset Perikanan Tangkap. vol 3(6): 351-356. https://doi.org/http://dx.doi.org/10.15578/ bawal.3.6.2011.351-356. 